CASSOWARY volume 4 (1): 68-86

ISSN : 2614-8900

E-ISSN : 2622-6545

Program Pascasarjana Universitas Papua, https://pasca.unipa.ac.id/

\title{
Keragaman morfologi dan genetik beberapa aksesi tanaman Sagu (Metroxylon sagu Rottb.) berdasarkan penanda molekuler gen mat-K
}

\author{
Eka Fitri Wulandari' ${ }^{1}$, Nouke Lenda Mawikere ${ }^{1,2}$, arahima Abbas $^{1,2 *}$ \\ ${ }^{1}$ Fakultas Pertanian, Universitas Papua, Jl. Gunung Salju Amban, Manokwari \\ ${ }^{2}$ Program Pascasarjana, Universitas Papua, Jl. Gunung Salju Amban, Manokwari \\ *E-mail: barahimabas@gmail.com
}

\begin{abstract}
Sago palm (Metroxylon sago Rottb.) is one of the carbohydrate-producing crops that has great potential in supporting food security programs. This study aims to determine the morphological and genetic diversity based on the mat-K gene marker of 15 accessions of sago pal that have been collected by the Sago Research Consortium. This research was conducted by preparing plant samples, extracting DNA, amplifying DNA with a PCR tools, visualizing the results of DNA amplification, sequencing, editing DNA sequencing, and blasting. The results showed that the sago palm accessions collected by the UNIPA Sago Research Consortium were morphologically different in the Russet stages. Based on the maturase $\mathrm{K}$ (mat-K) gene marker of 15 sago palm accessions were divided into two haplotypes, namely haplotype 1 which experienced deletion at base number 5 (amino acid phenylalanine) and haplotype 2 which did not experience deletion so it had phenylalanine amino acid. Phylogenetic analysis showed that 15 sago palm accessions were divided into 2 groups, namely group 1 and group 2. Sago palm were observed closely related to Metroxylon warburgii with genetic distance of 0.001 .
\end{abstract}

Keywords: maturase K, phylogenetic, Metroxylon sago, sago palm

\section{PENDAHULUAN}

Sagu (Metroxylon sagu Rottb.) merupakan salah satu tanaman penghasil karbohidrat yang sangat potensial dalam mendukung program ketahanan pangan (Tarigan, 2001). Potensi tanaman sagu di Indonesia cukup besar, karena memiliki areal yang luas. Diperkirakan sekitar 1.128 juta ha atau $51,3 \%$ dari luas areal sagu dunia terdapat di Indonesia, dengan daerah penyebaran utama adalah Maluku, Papua, dan beberapa daerah lain seperti di Sulawesi, Sumatera, dan Kalimantan. Sebagian besar lahan dalam bentuk hutan sagu dengan luasan berjumlah 1.067 .590 ha atau 90,3\% dan tanaman sagu yang semi budidaya sekitar 114.000 ha atau 9,7\% (Budianto, 2003).

Luas areal penyebaran sagu di Indonesia tidak menyebar rata begitu pula keragamannya. Flach (1983) memperkirakan keragaman sagu di Indonesia lebih tinggi dijumpai di Provinsi Papua dibanding dengan pulaupulau lainnya di Indonesia. Tanaman sagu di Indonesia beragam berdasarkan morfologi dan berdasarkan marker molekuler (Abbas 2018, Riyanto et al 2018). Keragaman sagu yang dimiliki saat ini mengalami erosi plasma nutfah dari tahun ke tahun (Tenda et al. 2006). Kondisi ini sejalan dengan tingkat konversi lahan atau hutan sagu menjadi 
lahan komoditas lain, bangunan, dan tingkat eksploitasi yang berlebihan.

Untuk menyelamatkan keragaman sagu, maka perlu dilakukan konservasi plasma nutfah. Konservasi plasma nutfah dapat dilakukan dengan cara in situ dan ex situ. Konservasi secara ex situ memerlukan informasi keragaman morfologi dan genetik tanaman yang akan dikonservasi agar efisien dalam penggunaan ruang dan penanganannya. Informasi keragaman morfologi dapat diungkap dengan mengidentifikasi karakter morfologi tanaman dan informasi keragaman genetik dapat diungkapkan melalui berbagai macam teknik molekuler seperti penanda RAPD (Abbas et al. 2009), penanda cpDNA (Abbas et al. 2010), penanda gen nad2 (Abbas et al 2019) dan penanda gen specifik (Abbas and Ehara 2012).

Salah satu teknik molekuler yang dapat digunakan yaitu DNA barkoding. DNA barkoding adalah satu atau lebih sekuen gen pendek yang diambil dari bagian genom standar dan digunakan untuk mengidentifikasi spesies (Kress dan Erickson, 2008). Beberapa kandidat gen yang disarankan untuk barkoding DNA tanaman kebanyakan berada pada DNA kloroplas, yang meliputi gen accD, mat-K, ndhJ, rpoB2, rpoC1, dan ycf5 (Chase et al., 2007, Lahaye et al., 2008); rbcL (Kress dan Erickson, 2007); trnL intron (Taberlet et al., 2007); dan trnHpsbA (Kress et al., 2005; Kress dan Erickson, 2007). Consortium for the Barcoding of Life (CBoL) merekomendasikan tiga gen yang dapat digunakan untuk barcoding yaitu rbcL, mat-K, dan ITS, sedangkan pada hewan sekuen DNA yang dapat dijadikan untuk barkoding adalah gen cytokrom c oksidasi (COI) di DNA mitokondria. Gen COI tidak dapat digunakan sebagai barkoding pada tanaman karena variabilitas yang rendah antar spesies.
Menurut Kress dan Erickson (2008), DNA barkoding dapat digunakan dalam bidang taksonomi dan filogenetik tumbuhan untuk hasil identifikasi tumbuhan yang lebih akurat dibandingkan dengan identifikasi secara morfologi. Salah satu DNA barkoding yang dapat digunakan yaitu matK (Maturase K) yang merupakan gen kloroplas berukuran sekitar 1500 pasang basa (bp) yang berlokasi di intron trnK. Hollingsworth et al., (2011) menyatakan bahwa saat ini gen matK telah digunakan sebagai alat yang penting untuk memeriksa keanekaragaman genetik intraspesies dan interspesies.

\section{BAHAN DAN METODE}

\section{Bahan Tanaman}

Bahan tanaman yang digunakan pada penelitian ini adalah 15 aksesi tanaman sagu koleksi Konsorsium Riset Sagu. Aksesi itu dikarakterisasi morfologinya yaitu warna daun tombak, warna pelepah, warna daun mudah berdasarkan color chart serta menentukan pola pendurian. Analisis DNA menggunakan sampel daun muda yang diambil dari tiap-tiap aksesi kemudian diekstrak DNAnya di Laboratorium Bioteknologi Unipa.

\section{Ekstraksi DNA}

Ekstraksi DNA dilakukan dengan menggunakan Genomic DNA mini kit (plant) GENEID. DNA genom diekstraksi dari daun sagu yang muda, dengan cara digerus hingga daun sagu menjadi halus kemudian dimasukkan ke dalam tube $1,5 \mathrm{ml}$ sebanyak $25 \mathrm{mg}$ dan dicampurkan dengan GPX1 buffer (400 $\mu 1)$ serta RNAse $(5 \mu \mathrm{l})$ menggunakan vortex dan spiner. Campuran tersebut diinkubasi pada suhu $60^{\circ} \mathrm{C}$ selama 10 menit menggunakan heat block. GP2 buffer sebanyak $100 \mu \mathrm{l}$ ditambahkan ke dalam campuran kemudian dihomogen- 
kan menggunakan vortex, setelah itu diinkubasikan dalam freezer selama 3 menit. Campuran tersebut dipindahkan ke dalam kolom filter yang dipasang dalam tube $2 \mathrm{ml}$, kemudian disentrifuges dengan kecepatan $5.000 \mathrm{rpm}$ selama 1 menit. Supernatant pada tube $2 \mathrm{ml}$ dipindahkan dengan hati-hati ke dalam tube $1,5 \mathrm{ml}$ yang baru. Volume lysate pada GP3 buffer 1,5 kali ditambahkan dan divortex selama 5 detik. Campuran $700 \mu \mathrm{L}$ dipindahkan ke dalam kolom GD yang telah diletakkan pada tube $2 \mathrm{ml}$, kemudian disentrifuges dengan kecepatan $15.000 \mathrm{rpm}$ selama 2 menit. Cairan yang keluar dari tube dibuang dan sisa campuran dimasukkan ke dalam kolom GD, kemudian disentrifuge pada kecepatan 15.000 rpm selama 2 menit. Cairan yang keluar dibuang dan kolom GD yang digunakan diletakkan pada tube $2 \mathrm{ml}$. W1 buffer $400 \mu \mathrm{L}$ ditambahkan pada saat kolom dicuci dan kemudian disentrifuge dengan kecepatan 15.000 rpm selama 30 detik. Wash buffer $600 \mu \mathrm{L}$ ditambahkan pada kolom yang dicuci setelah filtrate dibuang dan disentrifugasi pada $15.000 \mathrm{rpm}$ selama 30 detik. Kolom GD dikeringkan dengan disentrifugasi selama 3 menit pada kecepatan $15.000 \mathrm{rpm}$ dan filtrat dibuang. Kolom GD yang telah kering dipindahkan pada tube $1,5 \mathrm{ml}$ dan ditambahkan Elution Buffer $100 \mu \mathrm{L}$, kemudian dibiarkan selama 4 menit hingga Elution Buffer terserap oleh matriks. Selanjutnya disentrifuge pada kecepatan $15.000 \mathrm{rpm}$ selama 30 detik untuk mendapatkan DNA yang murni.

\section{Pengujian Kualitas DNA}

Gel agarose dibuat dengan cara menimbang agarose sebanyak 0,45 gram kemudian ditambahkan $45 \mathrm{ml} \mathrm{SB}$ buffer 1x. Campuran tersebut dipanaskan hingga mendidih dan dituangkan ke dalam cetakan gel elektroforesis saat suhunya sudah turun mendekati $40^{\circ} \mathrm{C}$ yang telah pasang sisir pada bagian tepihnya.

Gel dalam cetakan dimasukkan ke dalam camber elektroforesis dan ditambahkan SB buffer hingga gel terendam seluruhnya. Sisir yang digunakan untuk membentuk sumursumur diangkat dan sumur-sumur diisi dengan loading dye yang telah dicampur DNA genom. Ekstrak DNA $4 \mu \mathrm{l}$ dicampur dengan loading dye sebanyak $1 \mu 1$. Sumur terakhir diisi dengan marker $1 \mathrm{~kb}$ DNA ladder sebanyak $4 \mu 1$. Camber elektroforesis ditutup dan alirkan listrik menggunakan tegangan $110 \mathrm{~V}$ selama 25 menit. Selamjutnya gel hasil elektroforesis direndam ke dalam etidium bromide selama 15 menit, kemudian dibilas dengan air dan divisualisasi menggunakan UV transiluminator.

Ampilifikasi fragmen gen yang menyandi protein maturase $\mathrm{K}$ dilakukan dengan Polymerase Chain Reaction (PCR). Proses PCR menggunakan GoTaq Green (Promega). Total volume reaksi amplifikasi sebanyak $50 \mu 1$, yang terdiri atas $5 \mu \mathrm{l}$ DNA Template, $13 \mu \mathrm{l}$ $\mathrm{ddH}_{2} \mathrm{O}, 2,5 \mu \mathrm{l}$ primer MatK-1RKIM-f dan 2,5 $\mu$ l primer MatK-3FKIM-r, $1 \mu 1$ BSA, $1 \mu \mathrm{l}$ DMSO, dan $25 \mu \mathrm{l}$ GoTaq Green PCR Mix 2X. Profil suhu yang digunakan dalam thermocycler disajikan pada Tabel 1.

\section{Elektroforesis Produk PCR}

Gel agarose $1 \%(\mathrm{~b} / \mathrm{v})$ sebagai media penyangga dan larutan SB buffer $1 x$ digunakan untuk elektroforesis hasil amplifikasi PCR. Gel agarose dibuat dengan melarutkan 0,5 gram agarosa ke dalam $50 \mathrm{ml}$ SB buffer, campuran tersebut dipanaskan hingga mendidih dan dituangkan ke dalam cetakan gel elektroforesis pada saat suhu turun sekitar $40^{\circ} \mathrm{C}$ yang telah pasang sisir pada bagian tepihnya. Elektroforesis dilakukan pada tegangan $100 \mathrm{~V}$ selama 30 menit. 
Tabel 1. Tahapan amplifikasi DNA

\begin{tabular}{cllc}
\hline Tahapan & Suhu & Waktu & Jumlah Siklus \\
\hline Predenaturasi & $80^{\circ} \mathrm{C}$ & 10 detik & 1 \\
Denaturasi & $94^{\circ} \mathrm{C}$ & 5 menit & 1 \\
Denaturasi & $94^{\circ} \mathrm{C}$ & 30 detik & 40 kali \\
Annealing & $50^{\circ} \mathrm{C}$ & 30 detik & 40 kali \\
Extantion & $72^{\circ} \mathrm{C}$ & 45 detik & 40 kali \\
Extansion & $72^{\circ} \mathrm{C}$ & 7 menit & 1 \\
Extansion & $37^{\circ} \mathrm{C}$ & 1 menit & 1 \\
\hline
\end{tabular}

Gel yang telah dielektroforesis direndam ke dalam larutan ethidium bromide selama 15 menit dan dibilas dengan air, kemudian divisualisasi dengan menggunakan UV transiluminator. Dokumentasi dilakukan dengan menggunakan kamera digital.

\section{Sequensing Hasil PCR}

DNA 15 aksesi sagu yang telah diperoleh kemudian dikirim ke Singapore melalui PT Genetika Science Indonesia Jakarta untuk dilakukan sequensing dengan metode dideoksi terminasi Sanger oleh 1st base.

\section{HASIL DAN PEMBAHASAN}

\section{Morfologi Tanaman Sagu}

Karakterisasi penampilan morfologi suatu tanaman menjadi salah satu hal yang penting dalam pemuliaan tanaman. Hasil karakteristik merupakan salah satu sumber data yang dapat digunakan untuk upaya melakuakan kegiatan pemuliaan tanaman ataupun menentukan tetua guna menghasilkan bibit yang unggul. Penampilan karakter morfologi 15 aksesi sagu yang dikarakterisasi disajikan pada Gambar 1.

Hasil pengamatan morfologi 15 sampel sagu di lapangan ditemukan berbagai variasi, salah satunya pada warna daun tombak. Variasi warna daun tombak yaitu hijau, merah kehijauan, dan merah. Aksesi sagu 01, 03, 04, 05, 06, 08, dan 12 memiliki daun tombak berwarna merah kehijauan (RHS174B), aksesi sagu 07, 09, 10 dan 13 memiliki warna daun tombak hijau kekuningan (RHS142A), dan aksesi sagu 02, 11, 14, dan 15 memiliki warna daun tombak merah (RHS67A) (Gambar 2 dan Tabel 2). Menurut penelitian sebelumnya yang dilakukan oleh Riyanto et al., (2018) aksesi sagu memiliki 3 varian warna daun tombak yaitu merah, merah kehijauan, dan hijau. Perbedaan warna daun tombak pada aksesi sagu diduga karena adanya perbedaan waktu terekspresinya warna hijau daun (pigmen klorofil). Aksesi sagu yang memiliki daun tombak berwarna hijau, ketika daun tombak memasuki fase pemanjangan pigmen warna merah perlahan menghilang dan ketika sudah mencapai tinggi optimum warna merah sudah tidak tampak sama sekali. Aksesi sagu yang memiliki daun tombak berwarna merah kehijauan dan merah, ketika daun terbuka pigmen warna hijau masih belum terekspresi. Warna hijau akan terekspresi ketika daun berumur 810 hari setelah daun terbuka.

\section{Karakter Pendurian}

Tumbuhan sagu dibagi menjadi dua kelompok menurut penduriannya, yaitu berduri atau tidaknya tangkai daun (Harsanto 1986). Aksesi sagu 01, 02, 03, 07, 08, 10, 11, 09, dan 13 termasuk tanaman sagu yang tidak berduri dan aksesi sagu 04, 05, 06, 12, 14, dan 15 memiliki duri pada tangkai atau pelepah 
daunnya. Penampilan dan bentuk pendurian dari beberapa aksesi tanaman sagu disajikan pada Gambar 2 dan Tabel 2 .
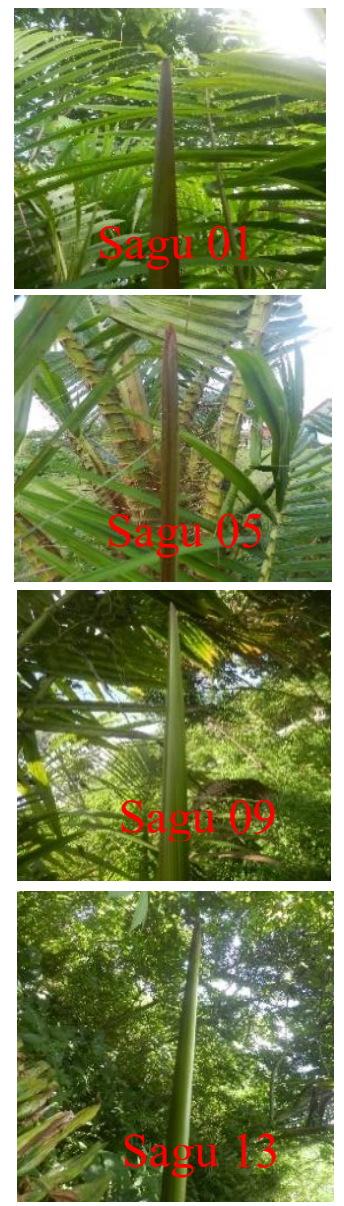
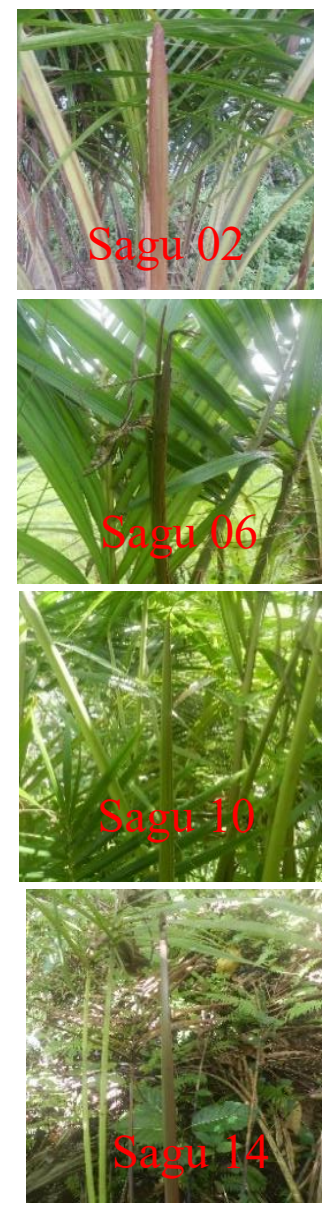

Gambar 1. Warna daun tombak 15 aksesi sagu
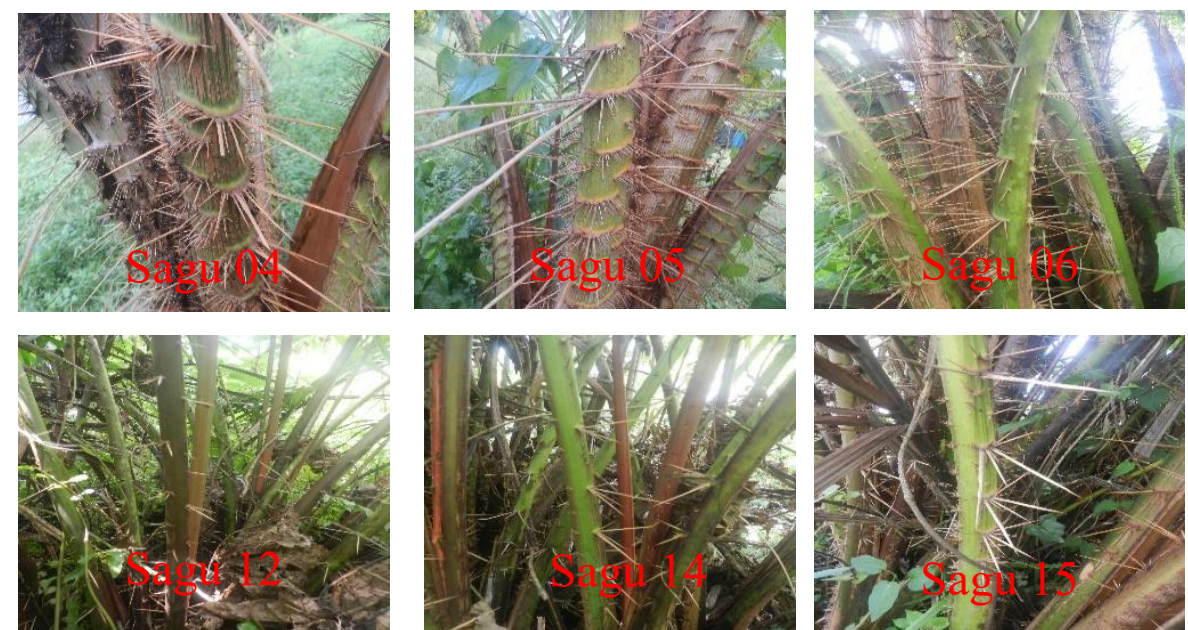

Gambar 2. Karakter pendurian dan bentuk cluster pendurian tanaman sagu pada stadia russet 


\section{Bentuk Cluster Pendurian}

Bentuk cluster duri pada bibit sagu terdiri dari 2 kategori, yaitu mengumpul dan menyebar. Kategori mengumpul yaitu setiap duri berada pada dudukan yang teratur di tengah pelepah dan di tepi pelepah. Kategori menyebar yaitu setiap duri memiliki posisi pada pelepah yang tidak beralur jelas atau tidak teratur (Riyanto et al., 2018).

Aksesi tanaman sagu yang dikarakterisasi dijumpai enam sampel sagu yang memiliki duri pada bagian pelepahnya, yaitu aksesi sagu 04, 05 dan 06 masuk dalam kategori duri yang mengumpul dan aksesi sagu 12, 14 dan 15 masuk dalam kategori duri menyebar (Gambar 3 dan Tabel 2).

\section{Warna Pelepah}

Pelepah muda dan tua pada bibit sagu juga memiliki variasi warna yang cukup mencolok. Bibit sagu memiliki 5 varian warna pelepah muda dan 2 varian warna pelepah tua. Pelepah muda memiliki lima warna yaitu merah tua, kuning pucat, merah muda kekuningan, hijau kekuningan, dan mosaik. Pelepah tua pada bibit sagu memiliki dua varian warna yaitu hijau tua dan hijau muda (Riyanto et al., 2018).

Warna pelepah muda pada sampel penelitian ini yaitu sampel aksesi 01, 06 dan 14 memiliki warna pelepah merah tua (RHS179A), aksesi sagu 02, 04, 09, $10,11,12,13$ dan 15 memiliki warna pelepah kuning pucat (RHS158), aksesi sagu 05 dan 14 memiliki warna pelepah merah muda kekuningan (RHS19A), aksesi sagu 07 memiliki warna pelepah hijau kekuningan (RHS142A), dan aksesi sagu 03 memiliki warna pelepah mosaik. Menurut Riyanto et al., (2018), pelepah muda mosaik yaitu pelepah yang terdiri lebih dari satu warna dengan pola yang tidak beraturan. Warna pelepah tua pada sampel penelitian ini terdiri atas aksesi sagu 01, 02, 08, 10, dan 15 memiliki pelepah yang berwarna hujau muda (RHS140C) dan aksesi sagu 03, 04, 05, 06, 07, 09, 11, 12, 13, dan 14 memiliki pelepah berwarna hijau tua (RHS140B) disajikan pada Gambar 3 dan Tabel 2.
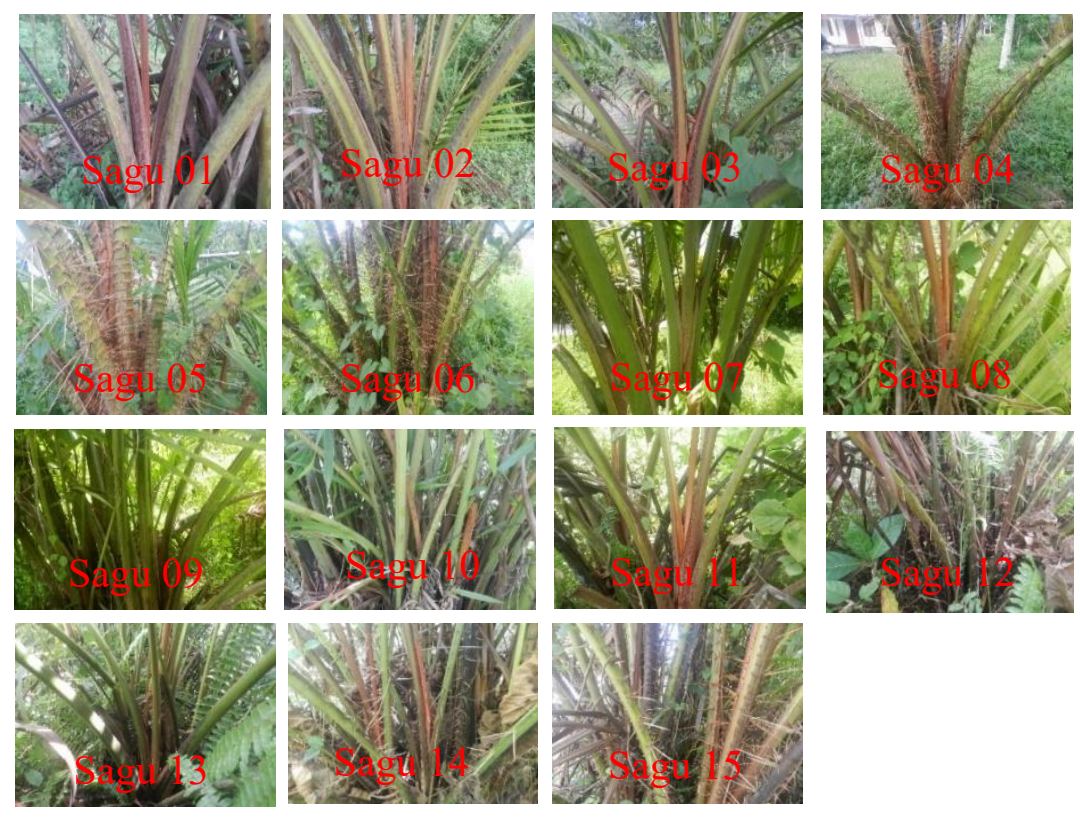

Gambar 3. Penampilan warna pelepah beberapa aksesi tanaman sagu pada stadia russet 
Tabel 2. Morfologi tanaman sagu pada stadia ruset

\begin{tabular}{|c|c|c|c|c|c|c|}
\hline No & Aksesi & $\begin{array}{l}\text { Karakter } \\
\text { pendurian }\end{array}$ & $\begin{array}{l}\text { Ukuran } \\
\text { klister }\end{array}$ & $\begin{array}{c}\text { Warna daun } \\
\text { tombak }\end{array}$ & $\begin{array}{l}\text { Warna pelepah } \\
\text { setelah daun } \\
\text { tombak terbuka }\end{array}$ & $\begin{array}{c}\text { Warna } \\
\text { pelepah ke } \\
\text { empat }\end{array}$ \\
\hline 1 & Sagu 01 & Tidak berduri & - & $\begin{array}{l}\text { RHS174B (Merah } \\
\text { kehijauan) }\end{array}$ & $\begin{array}{l}\text { RHS179A (Merah } \\
\text { tua) }\end{array}$ & $\begin{array}{c}\text { RHS140C } \\
\text { (Hijau muda) }\end{array}$ \\
\hline 2 & Sagu 02 & Tidak berduri & - & RHS67A (Merah) & $\begin{array}{c}\text { RHS158A } \\
\text { (Kuning pucat) }\end{array}$ & $\begin{array}{l}\text { RHS140C } \\
\text { (Hijau muda) }\end{array}$ \\
\hline 3 & Sagu 03 & Tidak berduri & - & $\begin{array}{c}\text { RHS174B (Merah } \\
\text { kehijauan) }\end{array}$ & Mosaic & $\begin{array}{l}\text { RHS140B } \\
\text { (Hijau tua) }\end{array}$ \\
\hline 4 & Sagu 04 & Berduri & Mengumpul & $\begin{array}{l}\text { RHS174B (Merah } \\
\text { kehijauan) }\end{array}$ & $\begin{array}{c}\text { RHS158A } \\
\text { (Kuning pucat) }\end{array}$ & $\begin{array}{l}\text { RHS140B } \\
\text { (Hijau tua) }\end{array}$ \\
\hline 5 & Sagu 05 & Berduri & Mengumpul & $\begin{array}{c}\text { RHS174B (Merah } \\
\text { kehijauan) }\end{array}$ & $\begin{array}{l}\text { RHS19A (Merah } \\
\text { muda kekuningan) }\end{array}$ & $\begin{array}{l}\text { RHS140C } \\
\text { (Hijau muda) }\end{array}$ \\
\hline 6 & Sagu 06 & Berduri & Mengumpul & $\begin{array}{l}\text { RHS174B (Merah } \\
\text { kehijauan) }\end{array}$ & $\begin{array}{l}\text { RHS179A } \\
\text { (Merah tua) }\end{array}$ & $\begin{array}{l}\text { RHS140B } \\
\text { (Hijau tua) }\end{array}$ \\
\hline 7 & Sagu 07 & Tidak berduri & - & $\begin{array}{l}\text { RHS142A (Hijau } \\
\text { kekuningan) }\end{array}$ & $\begin{array}{l}\text { RHS142A (Hijau } \\
\text { kekuningan) }\end{array}$ & $\begin{array}{l}\text { RHS140B } \\
\text { (Hijau tua) }\end{array}$ \\
\hline 8 & Sagu 08 & Tidak berduri & - & $\begin{array}{l}\text { RHS174B (Merah } \\
\text { kehijauan) }\end{array}$ & $\begin{array}{l}\text { RHS179A } \\
\text { (Merah tua) }\end{array}$ & $\begin{array}{l}\text { RHS140C } \\
\text { (Hijau muda) }\end{array}$ \\
\hline 9 & Sagu 09 & Tidak berduri & - & $\begin{array}{c}\text { RHS142A (Hijau } \\
\text { kekuningan) }\end{array}$ & $\begin{array}{c}\text { RHS158A } \\
\text { (Kuning pucat) }\end{array}$ & $\begin{array}{l}\text { RHS140B } \\
\text { (Hijau tua) }\end{array}$ \\
\hline 10 & Sagu 10 & Tidak berduri & - & $\begin{array}{l}\text { RHS142A (Hijau } \\
\text { kekuningan) }\end{array}$ & $\begin{array}{c}\text { RHS158A } \\
\text { (Kuning pucat) }\end{array}$ & $\begin{array}{l}\text { RHS140C } \\
\text { (Hijau muda) }\end{array}$ \\
\hline 11 & Sagu 11 & Tidak berduri & - & RHS67A (Merah) & $\begin{array}{c}\text { RHS158A } \\
\text { (Kuning pucat) }\end{array}$ & $\begin{array}{l}\text { RHS140B } \\
\text { (Hijau tua) }\end{array}$ \\
\hline 12 & Sagu 12 & Berduri & Menyebar & $\begin{array}{c}\text { RHS174B } \\
\text { (Merah kehijauan) }\end{array}$ & $\begin{array}{c}\text { RHS158A } \\
\text { (Kuning pucat) }\end{array}$ & $\begin{array}{l}\text { RHS140B } \\
\text { (Hijau tua) }\end{array}$ \\
\hline 13 & Sagu 13 & Tidak berduri & - & $\begin{array}{c}\text { RHS142A } \\
\text { (Hijau kekuningan) }\end{array}$ & $\begin{array}{c}\text { RHS158A } \\
\text { (Kuning pucat) }\end{array}$ & $\begin{array}{l}\text { RHS140B } \\
\text { (Hijau tua) }\end{array}$ \\
\hline 14 & Sagu 14 & Berduri & Menyebar & RHS67A (Merah) & $\begin{array}{l}\text { RHS19A (Merah } \\
\text { muda kekuningan) }\end{array}$ & $\begin{array}{l}\text { RHS140B } \\
\text { (Hijau tua) }\end{array}$ \\
\hline 15 & Sagu 15 & Berduri & Menyebar & RHS67A (Merah) & $\begin{array}{c}\text { RHS158A } \\
\text { (Kuning pucat) }\end{array}$ & $\begin{array}{c}\text { RHS140C } \\
\text { (Hijau muda) }\end{array}$ \\
\hline
\end{tabular}

\section{Amplikon Fragmen DNA Gen mat-K}

Hasil amplifikasi DNA dari 15 sampel tanaman sagu dan marker $1 \mathrm{~kb}$ DNA ladder (Thermoscientific) dengan ukuran pita DNA berkisar $250 \mathrm{bp}-$ 10000 bp, disajikan pada Gambar 4. Jumlah pita yang teramplifikasi menggunakan primer Maturase $\mathrm{K}$ berkisar 1000 bp. Hal ini menunjukkan bahwa produk PCR (amplikon) yang diperoleh adalah benar dari Gen Maturase $\mathrm{K}$ yang menjadi target dari primer MatK-1RKIM-f dan MatK3FKIM-r (Kuzmina et al., 2012).

Kualitas amplikon yang diperoleh cukup baik yang terlihat dari kecerahan pita DNA (sangat terang) disajikan pada Gambar 4. Kualitas amplikon akan berpengaruh terhadap hasil dari sekuensing DNA. Konsentrasi DNA yang rendah akan menyebabkan hasil sekuensing yang kurang bagus. Menurut Elviana (2010), konsentrasi DNA sampel, ukuran panjang primer, konsentrasi ion $\mathrm{Mg}$ dan suhu hibridasi primer harus dikontrol dengan hati-hati agar dapat diperoleh pita-pita DNA yang utuh dan baik.

\section{Urutan Sekuens Fragmen Gen Maturase K pada Tanaman Sagu}

Urutan sekuens fragmen gen mat-K yang diperoleh dalam format Ab1 file diedit dan dicocokkan dengan elektroferogramnya sehingga diperoleh urutan sekuens yang benar. Seluruh sekuens yang diperoleh memiliki kualitas elektroferogram yang baik. Penampilan sampel elektroferogram ditampilkan pada Gambar 7. Setiap basa 
nukleotida yang dihasilkan memberikan warna puncak yang berbeda-beda, yaitu Adenin berwarna hijau, Guanin berwarna ungu, Timin berwarna merah, dan Sitosin berwarna biru.

Hasil penggabungan sekuens forward dan reverse disimpan dalam bentuk fasta file yang digunakan dalam analisis selanjutnya. Panjang sekuens yang diperoleh yaitu $700 \mathrm{bp}$ (keompok I) dan 701 bp (kelompok II). Urutan sekuens DNA sampel sagu yang diteliti disajikan pada Tabel 3.

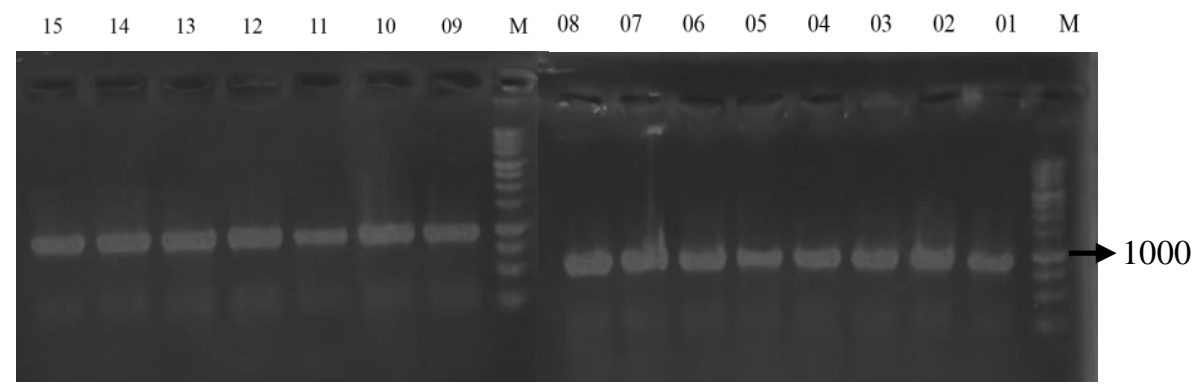

Gambar 4. Penampilan pola pita DNA hasil PCR

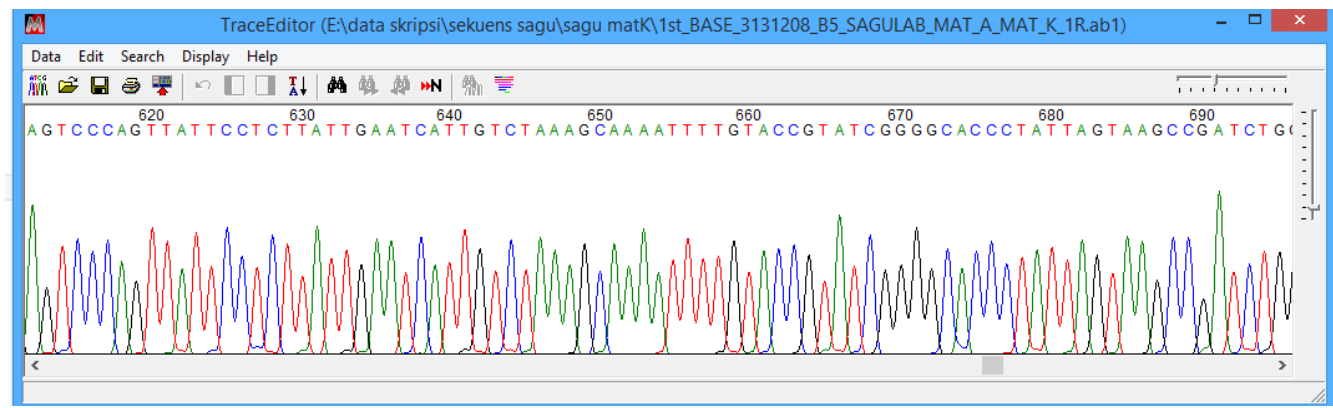

Gambar 5. Elektroferogram sampel sagu

Tabel 2. Urutan sekuens aksesi tanaman sagu kelompok I dan II

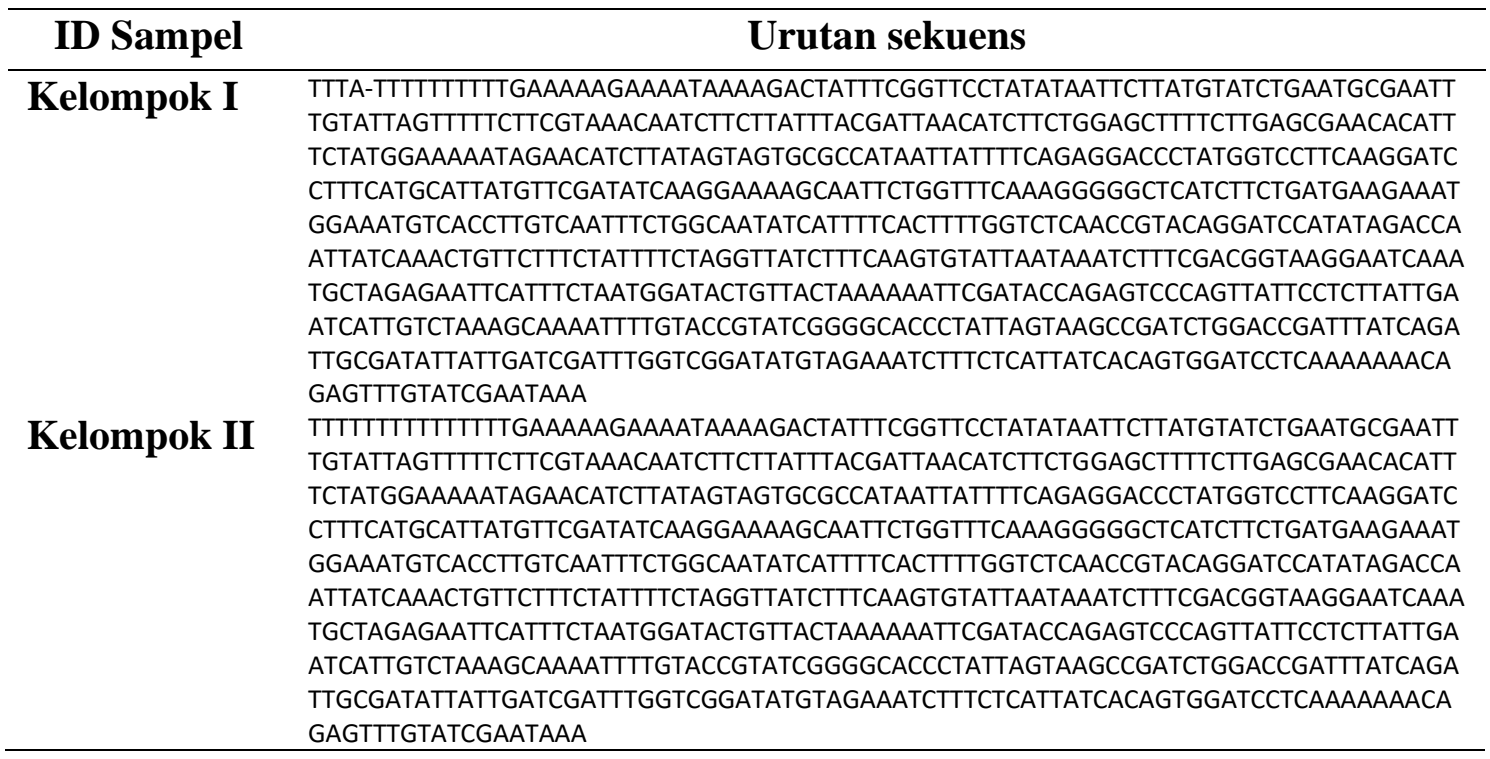




\section{Hasil Blast}

Menurut Barthet dan Hilu (2007), Gen mat-K yang digunakan sebagai gen penyandi protein memiliki model evolusi yang tidak biasa karena tingkat substitusi nukleotida gen mat-K tiga kali lebih tinggi dibandingkan gen rbcL dan tingkat substitusi asam amino enam kali lebih tinggi dibandingkan gen rbcL. Xiong (2006) menyatakan bahwa hasil dari pembacaan urutan nukleotida fragmen gen mat-K menghasilkan runutan DNA yang selanjutnya dapat dianalisis menggunakan BLAST pada situs NCBI. BLAST merupakan teknik untuk menyelaraskan urutan nukleotida sampel dengan membandingkan urutan nukleotida yang terdapat di dalam database GenBank. Hasil Blast 15 aksesi sagu dengan tanaman yang falmae lainnya disajikan pada Tabel 4 .

Tabel 3. Hasil blast tanaman sagu dengan tanaman selain sagu

\begin{tabular}{|c|c|c|c|c|c|}
\hline \multirow[t]{2}{*}{ No } & \multirow{2}{*}{$\begin{array}{c}\text { Sampel } \\
\text { ID }\end{array}$} & \multicolumn{4}{|c|}{ Hasil BLAST } \\
\hline & & Spesies & $\begin{array}{c}\text { Accession } \\
\text { number }\end{array}$ & $\begin{array}{c}\text { Query } \\
\text { coverage }\end{array}$ & Identity \\
\hline \multirow[t]{5}{*}{1} & \multirow[t]{5}{*}{ Sagu 01} & Metroxylon warburgii & KT312926.1 & $99 \%$ & $100 \%$ \\
\hline & & Metroxylon salomonense & AM114548.1 & $100 \%$ & $99,71 \%$ \\
\hline & & Salacca ramosiana & KT312921.1 & $99 \%$ & $99,71 \%$ \\
\hline & & Pigafetta elata & KT312923.1 & $100 \%$ & $99,43 \%$ \\
\hline & & Pigafetta elata & AM114549.1 & $100 \%$ & $99,43 \%$ \\
\hline \multirow[t]{5}{*}{2} & \multirow[t]{5}{*}{ Sagu 02} & Metroxylon warburgii & KT312926.1 & $99 \%$ & $100 \%$ \\
\hline & & Metroxylon salomonense & AM114548.1 & $100 \%$ & $99,71 \%$ \\
\hline & & Salacca ramosiana & KT312921.1 & $99 \%$ & $99,71 \%$ \\
\hline & & Pigafetta elata & КT312923.1 & $100 \%$ & $99,43 \%$ \\
\hline & & Pigafetta elata & AM114549.1 & $99 \%$ & $99,43 \%$ \\
\hline \multirow[t]{5}{*}{3} & \multirow[t]{5}{*}{ Sagu 03} & Metroxylon warburgii & KT312926.1 & $100 \%$ & $99,86 \%$ \\
\hline & & Metroxylon salomonense & AM114548.1 & $100 \%$ & $99,72 \%$ \\
\hline & & Salacca ramosiana & KT312921.1 & $100 \%$ & $99,57 \%$ \\
\hline & & Pigafetta elata & KT312923.1 & $100 \%$ & $99,57 \%$ \\
\hline & & Pigafetta elata & AM114549.1 & $100 \%$ & $99,57 \%$ \\
\hline \multirow[t]{5}{*}{4} & \multirow[t]{5}{*}{ Sagu 04} & Metroxylon warburgii & KT312926.1 & $100 \%$ & $99,86 \%$ \\
\hline & & Metroxylon salomonense & AM114548.1 & $100 \%$ & $99,72 \%$ \\
\hline & & Salacca ramosiana & KT312921.1 & $100 \%$ & $99,57 \%$ \\
\hline & & Pigafetta elata & KT312923.1 & $100 \%$ & $99,57 \%$ \\
\hline & & Pigafetta elata & AM114549.1 & $100 \%$ & $99,57 \%$ \\
\hline \multirow[t]{5}{*}{6} & \multirow[t]{5}{*}{ Sagu 06} & Metroxylon warburgii & KT312926.1 & $100 \%$ & $99,86 \%$ \\
\hline & & Metroxylon salomonense & AM114548.1 & $100 \%$ & $99,72 \%$ \\
\hline & & Salacca ramosiana & KT312921.1 & $100 \%$ & $99,57 \%$ \\
\hline & & Pigafetta elata & KT312923.1 & $100 \%$ & $99,57 \%$ \\
\hline & & Pigafetta elata & AM114549.1 & $100 \%$ & $99,57 \%$ \\
\hline \multirow[t]{5}{*}{7} & \multirow[t]{5}{*}{ Sagu 07} & Metroxylon warburgii & KT312926.1 & $100 \%$ & $99,86 \%$ \\
\hline & & Metroxylon salomonense & AM114548.1 & $100 \%$ & $99,72 \%$ \\
\hline & & Salacca ramosiana & KT312921.1 & $100 \%$ & $99,57 \%$ \\
\hline & & Pigafetta elata & KT312923.1 & $100 \%$ & $99,57 \%$ \\
\hline & & Pigafetta elata & AM114549.1 & $100 \%$ & $99,57 \%$ \\
\hline \multirow[t]{5}{*}{8} & \multirow[t]{5}{*}{ Sagu 08} & Metroxylon warburgii & KT312926.1 & $100 \%$ & $99,86 \%$ \\
\hline & & Metroxylon salomonense & AM114548.1 & $100 \%$ & $99,72 \%$ \\
\hline & & Salacca ramosiana & KT312921.1 & $100 \%$ & $99,57 \%$ \\
\hline & & Pigafetta elata & КT312923.1 & $100 \%$ & $99,57 \%$ \\
\hline & & Pigafetta elata & AM114549.1 & $100 \%$ & $99,57 \%$ \\
\hline
\end{tabular}


Lanjutan Tabel 4

\begin{tabular}{|c|c|c|c|c|c|}
\hline \multirow[b]{2}{*}{ No } & \multirow{2}{*}{$\begin{array}{c}\text { Sampel } \\
\text { ID }\end{array}$} & \multicolumn{4}{|c|}{ Hasil BLAST } \\
\hline & & Spesies & $\begin{array}{c}\text { Accession } \\
\text { number }\end{array}$ & $\begin{array}{c}\text { Query } \\
\text { coverage }\end{array}$ & Identity \\
\hline \multirow[t]{5}{*}{9} & Sagu 9 & Metroxylon warburgii & KT312926.1 & $100 \%$ & $99,86 \%$ \\
\hline & & Metroxylon salomonense & AM114548.1 & $100 \%$ & $99,72 \%$ \\
\hline & & Salacca ramosiana & KT312921.1 & $100 \%$ & $99,57 \%$ \\
\hline & & Pigafetta elata & KT312923.1 & $100 \%$ & $99,57 \%$ \\
\hline & & Pigafetta elata & AM114549.1 & $100 \%$ & $99,57 \%$ \\
\hline \multirow[t]{5}{*}{10} & Sagu 10 & Metroxylon warburgii & KT312926.1 & $100 \%$ & $99,86 \%$ \\
\hline & & Metroxylon salomonense & AM114548.1 & $100 \%$ & $99,72 \%$ \\
\hline & & Salacca ramosiana & KT312921.1 & $100 \%$ & $99,57 \%$ \\
\hline & & Pigafetta elata & KT312923.1 & $100 \%$ & $99,57 \%$ \\
\hline & & Pigafetta elata & AM114549.1 & $100 \%$ & $99,57 \%$ \\
\hline \multirow[t]{5}{*}{11} & Sagu 11 & Metroxylon warburgii & KT312926.1 & $100 \%$ & $99,86 \%$ \\
\hline & & Metroxylon salomonense & AM114548.1 & $100 \%$ & $99,72 \%$ \\
\hline & & Salacca ramosiana & KT312921.1 & $100 \%$ & $99,57 \%$ \\
\hline & & Pigafetta elata & KT312923.1 & $100 \%$ & $99,57 \%$ \\
\hline & & Pigafetta elata & AM114549.1 & $100 \%$ & $99,57 \%$ \\
\hline \multirow[t]{5}{*}{12} & Sagu 12 & Metroxylon warburgii & KT312926.1 & $99 \%$ & $100 \%$ \\
\hline & & Metroxylon salomonense & AM114548.1 & $100 \%$ & $99,71 \%$ \\
\hline & & Salacca ramosiana & KT312921.1 & $99 \%$ & $99,71 \%$ \\
\hline & & Pigafetta elata & KT312923.1 & $100 \%$ & $99,43 \%$ \\
\hline & & Pigafetta elata & AM114549.1 & $100 \%$ & $99,43 \%$ \\
\hline \multirow[t]{5}{*}{13} & Sagu 13 & Metroxylon warburgii & KT312926.1 & $100 \%$ & $99,86 \%$ \\
\hline & & Metroxylon salomonense & AM114548.1 & $100 \%$ & $99,72 \%$ \\
\hline & & Salacca ramosiana & KT312921.1 & $100 \%$ & $99,57 \%$ \\
\hline & & Pigafetta elata & KT312923.1 & $100 \%$ & $99,57 \%$ \\
\hline & & Pigafetta elata & AM114549.1 & $100 \%$ & $99,57 \%$ \\
\hline \multirow[t]{10}{*}{14} & Sagu 14 & Metroxylon warburgii & KT312926.1 & $100 \%$ & $99,86 \%$ \\
\hline & & Metroxylon salomonense & AM114548.1 & $100 \%$ & $99,72 \%$ \\
\hline & & Salacca ramosiana & KT312921.1 & $100 \%$ & $99,57 \%$ \\
\hline & & Pigafetta elata & KT312923.1 & $100 \%$ & $99,57 \%$ \\
\hline & & Pigafetta elata & AM114549.1 & $100 \%$ & $99,57 \%$ \\
\hline & Sagu 15 & Metroxylon warburgii & KT312926.1 & $99 \%$ & $100 \%$ \\
\hline & & Metroxylon salomonense & AM114548.1 & $100 \%$ & $99,71 \%$ \\
\hline & & Salacca ramosiana & KT312921.1 & $99 \%$ & $99,71 \%$ \\
\hline & & Pigafetta elata & KT312923.1 & $100 \%$ & $99,43 \%$ \\
\hline & & Pigafetta elata & AM114549.1 & $100 \%$ & $99,43 \%$ \\
\hline
\end{tabular}

Berdasarkan hasil blast pada penelitian ini menunjukkan bahwa 15 sampel yang diuji dibandingkan dengan spesies tanaman lainnya di GenBank, berdasarkan Accession number, Query coverage, dan Identitynya dapat dikelompokkan menjadi 2 kelompok. Kelompok 1 terdiri dari sampel sagu 01, 02, 08, 12, 15 dan kelompok 2 terdiri dari sampel sagu 03, 04, 05, 06, 07, 09, 10, $11,13,14$. Keragaman genetik tanaman sagu berdasarkan market gen matK juga membagi aksesi menjadi dua bagian genotype (Abbas et al 2020).
Nugraha et al., (2014) menyatakan bahwa nilai Query coverage menunjukkan persentase sampel yang terpakai di dalam analisis BLAST. Menurut Daniels et al., (2013), urutan nukleotida dikatakan identik apabila memiliki nilai minimal Query coverage sebesar $40 \%$. Pada penelitian ini nilai Query coverage pada masing-masing kelompok, yaitu kelompok 1 dibandingkan dengan $\mathrm{Me}$ troxylon warburrgi dan Salacca ramosiana adalah sebesar 99\%. Pada spesies Meroxylon salomonanse dan Pigafetta elata memiliki Query coverage 
sebesar $100 \%$. Untuk kelompok 2 jika dibandingkan dengan spesies palmae memiliki nilai Query coverage sebesar $100 \%$. Dari data tersebut dapat dikatakan bahwa urutan nukleotida dari masingmasing sampel identik dengan spesies palmae yang telah disebutkan sebelumnya.

Identity merupakan nilai tertinggi dari persentase identitas atau kecocokan antara urutan nukleotida Query dengan urutan nukleotida database yang disejajarkan (Altschul et al., 1990). Semakin tinggi nilai Identity maka semakin cocok urutan nukleotida sampel dengan urutan nukleotida database. Pada penelitian ini masing-masing sampel memiliki nilai identity yang sangat tinggi, yaitu $99,43 \%$ sampai $100 \%$. Dengan demikian dapat dikatakan bahwa urutan nukleotida sampel cocok dengan urutan nukleotida database. Accession number merupakan nomor aksesi atau penomoran khusus bagi tiap record (Nugraha et al., 2014). Accession number dalam penelitian ini adalah nomor aksesi dari spesies palmae lain yang diambil dari GenBank.

\section{Karakter Fragmen DNA Sagu Berdasarkan Marker Gen mat-K}

\section{Komposisi nukleutida}

Menurut Sambrook dan Russell (2001), perunutan DNA dapat membantu dalam hal merunut nukleotida yang ada, berbeda, ataupun bermutasi. Keragaman genetik dapat muncul karena adanya mutasi, aliran gen, migrasi, dan proses seleksi.

Berdasarkan komposisinya nukleotida $(T / U)$ pada semua individu memiliki persentase yang berbeda-beda, yaitu pada sampel sagu 01, 02, 08, 12 dan 15 memiliki persentase sebesar $36,1 \%$, sedangkan pada sampel sagu 03, 04, 05, 06, 07, 09, 10, 11, 13 dan 14 memiliki persentase sebesar $36,4 \%$. Komposisi nukleotida sitosin (C) pada semua sampel sagu memiliki persentase yang sama, yaitu sebesar $17,0 \%$. Komposisi nukleotida adenin (A) paling banyak pada sampel sagu 03, 04, 05, 06, 07, 09, $10,11,13$ dan 14 yaitu sebesar $30,6 \%$ dan pada sampel sagu 01, 02, 08, 12 dan 15 sebesar 30,4\%. Komposisi nukleotida guanin $(\mathrm{G})$ pada setiap sampel memiliki nilai persentase yang sama, yaitu sebesar $16,3 \%$.

Jika keseluruhan sampel ditambah dengan data palmae lainnya, rata-rata komposisi nukleotida (T/U) sebesar $36,3 \%$, sitosin (C) sebesar 17,0\%, adenin (A) sebesar 30,4\%, dan guanin (G) sebesar $16,3 \%$, sehingga total rata-rata komposisi nukleotida penyusun sebesar 100\% dengan jumlah basa berkisar 700 bp sampai 701 bp. Terlihat bahwa komposisi nukleotidanya tidak memiliki selisih komposisi yang jauh. Menurut situs Open Course Ware (2009) jumlah adenin dengan timin selalu sama dalam DNA suatu organisme, demikian juga terjadi pada jumlah guanin dan sitosin. Komposisi nukleotida dari hasil sekuen setiap sampel dapat dilihat pada Tabel 5.

\section{Polimorfisme DNA}

Hasil analisis polimorfisme tanaman sagu dibagi menjadi dua kelompok, yaitu kelompok 1 dan kelompok 2 (Tabel 6). Kelompok 1 terdiri dari sampel sagu 01, 02, 08, 12 dan 15, sedangkan kelompok 2 terdiri dari sampel 03, 04, 05, 06, 07, 09, 10, 11, 13 dan 14. Kelompok tersebut hanya ada satu perbedaan nukleotida, yaitu nukleotida Adenin (A) pada kelompok 1 dan nukleotida Timin (T) pada kelompok 2 dengan posisi urutan yang sama yaitu pada urutan ke-4. Kesamaan urutan nukleotida dari kedua kelompok tersebut adalah 99,9\%. Mengikuti pola penelitian terdahulu yang dilakukan oleh Lawodi et al., (2013) mendapatkan bahwa primer MatK-1RKIM-f dan MatK-3FKIM-r 
berhasil digunakan untuk memperkuat gen mat-K dari tomat lokal Sulawesi (L. esculentum). Hanya ada satu perbedaan nukleotida antara tomat dengan tomat kecil atau tomat cherry dan kesamaan urutan keduanya jenis tomat ini adalah 99,9\% bila dibandingkan dengan data base GenBank. Perbedaan urutan itu sama tingginya dengan 3 nukleotida dengan urutan yang sama dalam beberapa spesies $L$. esculentum yaitu $99,64 \%$.

Data yang diperoleh yang dibandingkan dengan data base GenBank, maka kelompok 1 dengan nukleotida adenin (A) pada posisi 4 berbeda dengan Metroxylon warburgii (kode akses KT312926.1) pada nukleotida Cytosine. Urutan 548 dengan nukleotida Cytosine berbeda dengan data base Genbank Metroxylon salomonense (kode akses AM114548.1) pada nukleotida Timin. Hal ini berarti bahwa hanya ada satu urutan nukleotida yang berbeda, sehingga memiliki kesamaan sebesar 99,9\%. Kelompok 1 pada posisi 4, 9, 188, dan 549 berbeda dengan data base Pigafetta elata dengan kode akses KT312923.1 pada nukleotida adenin dan timin. Posisi nukleotida 4, 337, dan 549 yang membedakan dengan data base Salacca ramosiana (kode akses KT312921.1) pada nukeotida cytosin dan timin. Pada posisi 4, 9, 188, dan 549 terdapat perbedaan dengan data base Pigafetta elata (kode akses AM114549.1) pada nukleotida Timin dan Adenin.

Tabel 4. Komposisi nukleotida pada 15 sampel tanaman sagu yang diuji

\begin{tabular}{lcccccc}
\hline & \multicolumn{5}{c}{ Komposisi Nukleotida (\%) } & Jumlah \\
& T(U) & C & A & G & Total & basa \\
\hline Sagu 01 & 36.1 & 17.0 & 30.6 & 16.3 & 100 & 700.0 \\
Sagu 02 & 36.1 & 17.0 & 30.6 & 16.3 & 100 & 700.0 \\
Sagu 03 & 36.4 & 17.0 & 30.4 & 16.3 & 100 & 701.0 \\
Sagu 04 & 36.4 & 17.0 & 30.4 & 16.3 & 100 & 701.0 \\
Sagu 05 & 36.4 & 17.0 & 30.4 & 16.3 & 100 & 701.0 \\
Sagu 06 & 36.4 & 17.0 & 30.4 & 16.3 & 100 & 701.0 \\
Sagu 07 & 36.4 & 17.0 & 30.4 & 16.3 & 100 & 701.0 \\
Sagu 08 & 36.1 & 17.0 & 30.6 & 16.3 & 100 & 700.0 \\
Sagu 09 & 36.4 & 17.0 & 30.4 & 16.3 & 100 & 701.0 \\
Sagu 10 & 36.4 & 17.0 & 30.4 & 16.3 & 100 & 701.0 \\
Sagu 11 & 36.4 & 17.0 & 30.4 & 16.3 & 100 & 701.0 \\
Sagu 12 & 36.1 & 17.0 & 30.6 & 16.3 & 100 & 700.0 \\
Sagu 13 & 36.4 & 17.0 & 30.4 & 16.3 & 100 & 701.0 \\
Sagu 14 & 36.4 & 17.0 & 30.4 & 16.3 & 100 & 701.0 \\
Sagu 15 & 36.1 & 17.0 & 30.6 & 16.3 & 100 & 700.0 \\
KT312926.1 Metroxylon warburgii & 36.2 & 17.1 & 30.4 & 16.3 & 100 & 701.0 \\
AM114548.1 Metroxylon salomonense & 36.4 & 16.8 & 30.5 & 16.3 & 100 & 701.0 \\
KT312923.1 Pigafetta elata & 36.4 & 17.0 & 30.5 & 16.1 & 100 & 701.0 \\
KT312921.1 Salacca ramosiana & 36.5 & 17.0 & 30.2 & 16.3 & 100 & 701.0 \\
AM114549.1 Pigafetta elata & 36.4 & 17.0 & 30.5 & 16.1 & 100 & 701.0 \\
\hline Rata-rata & 36.3 & 17.0 & 30.4 & 16.3 & 100 & 700.8 \\
\hline
\end{tabular}


Tabel 5. Hasil polimorfisme tanaman sagu

\begin{tabular}{|c|c|c|c|c|c|c|}
\hline \multirow{2}{*}{ ID Sampel } & \multicolumn{6}{|c|}{ Untaian DNA } \\
\hline & 4 & 9 & 188 & 337 & 548 & 549 \\
\hline Sagu 01 & A & $\mathrm{T}$ & $\mathrm{G}$ & $\mathrm{C}$ & $\mathrm{C}$ & $\mathrm{A}$ \\
\hline Sagu 02 & . & . & . & . & . & . \\
\hline Sagu 03 & $\mathrm{~T}$ & . & . & . & . & . \\
\hline Sagu 04 & $\mathrm{~T}$ & . & . & . & . & . \\
\hline Sagu 05 & $\mathrm{~T}$ & . & . & . & . & . \\
\hline Sagu 06 & $\mathrm{~T}$ & . & . & . & . & . \\
\hline Sagu 07 & $\mathrm{~T}$ & . & . & . & . & . \\
\hline Sagu 08 & . & . & . & . & . & . \\
\hline Sagu 09 & $\mathrm{~T}$ & . & . & . & . & . \\
\hline Sagu 10 & $\mathrm{~T}$ & . & . & . & . & . \\
\hline Sagu 11 & $\mathrm{~T}$ & . & . & . & . & . \\
\hline Sagu 12 & . & . & . & . & . & . \\
\hline Sagu 13 & $\mathrm{~T}$ & . & . & . & . & . \\
\hline Sagu 14 & $\mathrm{~T}$ & . & . & . & . & . \\
\hline Sagu 15 & . & . & . & . & . & . \\
\hline KT312926.1 Metroxylon warburgii & $\mathrm{C}$ & . & . & . & . & . \\
\hline AM114548.1 Metroxylon salomonense & . & . & . & . & $\mathrm{T}$ & . \\
\hline KT312923.1 Pigafetta elata & $\mathrm{T}$ & A & A & . & . & $\mathrm{T}$ \\
\hline KT312921.1 Salacca ramosiana & $\mathrm{C}$ & . & . & $\mathrm{T}$ & . & $\mathrm{T}$ \\
\hline AM114549.1 Pigafetta elata & $\mathrm{T}$ & A & A & . & . & $\mathrm{T}$ \\
\hline
\end{tabular}

Kelompok 2 jika dibandingkan dengan data base GenBank Metroxylon warburgii dengan kode akses KT312926.1 memiliki perbedaan pada posisi 4 untuk nukleotida Timin dan Cytocine. Pada urutan 548 kelompok 2 dengan nukleotida cytosin berbeda dengan data base Metroxylon salomonense (kode akses AM114548.1) yang memiliki nukleotida Timin. Pada untaian 9, 188, dan 549 memiliki perbedaan pada nukleotida andenin dan timin apabila dibandingkan dengan data base Pigafetta elata dengan kode akses KT312923.1. Jika dibandingankan dengan Salacca ramosiana dengan kode akses AM114548.1, perbedaan terdapat pada untaian 4, 337, dan 549 pada nukleotida Cytosin dan Timin. Pada data base Pigafetta elata dengan kode akses
AM114549.1 memiliki perbedaan dengan untaian 9, 188 dan 549 pada nukleotida Adenin dan Timin.

\section{Haplotipe}

Berdasarkan hasil polimorfisme 15 aksesi sagu dikelompokkan menjadi dua haplotipe yaitu haplotipe tipe 1 dan haplotipe tipe 2. Haplotipe 1 terdiri sampel sagu 01, 02, 08, 12, dan 15, sedangkan haplotipe 2 terdiri dari sampel 03, 04, 05, 06, 07, 09, 10, 11, 13, dan 14 (Tabel 5). Tipe haplotipe 1 memiliki ciri khas pada urutan basa nukleotida yaitu Adenin (A) pada posisi nukleotida urutan ke 4, sedangkan tipe haplotipe 2 memiliki ciri khas pada urutan basa nukleotida yaitu Timin (T) pada posisi nukleotida ke 6 . 
Polimorfisme haplotipe 1 dan haplotipe 2 berbeda dengan haplotipe referensi dari data GenBank. Perbeda dapat terlihat pada nukleotida-nukleotida penyusunnya. Keragaman haplotipe dapat menunjukkan tingkat keragaman genetik. Haplotipe yang semakin beragam menandakan tingkat keragaman genetik semakin tinggi. Pada penelitian ini 15 aksesi sagu hanya mendapatkan dua haplotipe berarti tidak menujukkan adanya keragaman genetik yang tinggi, namun apabila dibandingkan dengan data base GenBank maka memiliki tingkat keragaman yang cukup tinggi.

\section{Urutan asam amino}

Urutan asam amino dari 15 sampel sagu, hanya diambil perwakilan sampel dari setiap haplotipe untuk analisis urutan asam amino. Haplotipe 1 diwakilkan oleh sampel sagu 01 dan haplotipe 2 diwakilkan oleh sampel sagu 03. Analisis urutan asam amino menggunakan aplikasi MEGA 5.2 (Molecular Evolutionary Genetic Analysis) (Tamura et al., 2011) menghasilkan panjang $701 \mathrm{bp}$ nukleotida yang terdiri dari 233 asam amino. Analisis berdasarkan variable sites hanya terdapat 1 asam amino yang berbeda seperti pada Tabel 7 .

Pada Tabel 7 terlihat bahwa dari 233 asam amino hanya ditemukan satu asam amino yang berbeda di antara individu, yaitu pada sampel sagu 01 mengalami delesi asam amino urutan ke 2, yaitu Phenylalanine (F). Sampel sagu 03 memiliki asam amino Phenylalanine $(F)$. Perbedaan ini dikarenakan adanya delesi pada nukleotida nomor 5 yang berada dalam kelompok haplotipe 1 .

\section{Komposisi asam amino}

Komposisi asam amino diwakilkan oleh 2 sampel tanaman sagu, yaitu sampel sagu 01 yang mewakilkan haplotipe 1 dan sampel sagu 03 yang mewakilkan haplotipe 2. Komposisi asam amino berdasarkan analisis mengunakan aplikasi MEGA 5.2 (Molecular Evolutionary Genetic Analysis) (Tamura et al., 2011) mendapatkan hasil seperti pada Tabel 8.

Tabel 7. Urutan asam amino sampel sagu yang diuji berdasarkan market Mat-K gen

\begin{tabular}{|l|l|l|}
\hline No & ID Sampel & Urutan Asam amino \\
\hline 1 & Sagu 01 & F?FFFEKENKRLFRFLYNSYVSECEFVLVFLRKQS SYLRLTS \\
& (Haplotipe 1) & SGAFLERTHFYGKIEHLIVVRHNYFQRTLWSFKDPFMHYVRY \\
& & QGKAILVSKGAHLLMKKWKCHLVNFWQYHFHFWSQPYRIHID \\
& & QLSNCSFYFLGYLSSVLINLSTVRNQMLENSFLMDTVTKKFD \\
& & TRVPVIPLIESLSKAKFCTVSGHPISKP IWTDLSDCDI IDRF \\
& & GRICRNLSHYHSGSSKKQSLYRI \\
\hline 2 & Sagu 03 & FFFFFEKENKRLFRFLYNSYVSECEFVLVFLRKQSSYLRLTS \\
& (Haplotipe 1) & SGAFLERTHFYGKIEHLIVVRHNYQRTLWSFKDPFMHYVRY \\
& & QGKAILVSKGAHLLMKKWKCHLVNFWQYHFHFWSQPYRIHID \\
& & QLSNCSFYFLGYLSSVLINLSTVRNQMLENSFLMDTVTKKFD \\
& & TRVPVIPLIESLSKAKFCTVSGHPISKP IWTDLSDCDI IDRF \\
& & GRICRNLSHYHSGSSKKQSLYRI \\
\hline
\end{tabular}


Tabel 8. Komposisi asam amino sampel sagu yang dianalisis berdasarkan marker mat-K gen

\begin{tabular}{ccc}
\hline \multirow{2}{*}{ Asam amino } & \multicolumn{2}{c}{ ID sampel } \\
\cline { 2 - 3 } & Sagu 01 & Sagu 03 \\
\hline Ala (A) & 1.7 & 1.7 \\
Cys (C) & 2.6 & 2.6 \\
Asp (D) & 3.4 & 3.4 \\
Glu (E) & 3.4 & 3.4 \\
Phe (F) & 9.5 & 9.9 \\
Gly (G) & 3.4 & 3.4 \\
His (H) & 5.2 & 5.2 \\
Ile (I) & 6.0 & 6.0 \\
Lys (K) & 7.3 & 7.3 \\
Leu (L) & 10.8 & 10.7 \\
Met (M) & 1.7 & 1.7 \\
Asn (N) & 3.9 & 3.9 \\
Pro (P) & 2.6 & 2.6 \\
Gln (Q) & 3.4 & 3.4 \\
Arg (R) & 6.5 & 6.4 \\
Ser (S) & 10.8 & 10.7 \\
Thr (T) & 3.9 & 3.9 \\
Val (V) & 6.0 & 6.0 \\
Trp (W) & 2.2 & 2.1 \\
Tyr (Y) & 5.6 & 5.6 \\
\hline
\end{tabular}

Komposisi asam amino dari sampel sagu 01 dan sampel sagu 03 memiliki beberapa perbedaan pada asam amino penyusunnya. Contoh pada asam amino Phenylalanine (Phe), komposisinya memiliki rentang perbedaan yang cukup jauh dibandingkan komposisi asam amino lainnya yaitu $9,5 \%$ untuk sampel sagu 01, sampel sagu 03 memiliki asam amino yang lebih tinggi yaitu sebesar 9,9\%. 20 asam amino tanaman sagu memiliki komposisi tertinggi sebesar $10,8 \%$ pada asam amino Leucine (Leu) untuk sampel sagu 01 dan sagu 03 sebesar $10,7 \%$, sama halnya pada asam amino Serine (Ser). Komposisi yang paling rendah sebesar $1,7 \%$ pada asam amino Alanine dan Methionine untuk sampel sagu 01 dan sagu 03.

\section{Filogenetik Tanaman Sagu dan Famili Palmae Lainnya}

Menurut Saitou dan Imanishi (1989), konstruksi pohon filogenetika adalah hal yang terpenting dan menarik dalam studi evolusi. Beberapa metode dapat digunakan untuk mengkonstruksi pohon filogenetika dari data molekuler (nukleotida atau asam amino), salah satunya adalah metode UPGMA. Diagram filogenetik dikonstruksi menggunakan metode UPGMA model kimura-2 dan analisis Bootstrap 1000 replikasi disajikan pada Gambar 8. Nilai bootstrap sebanyak 100 sampai 1000 ulangan digunakan untuk memperkirakan tingkat kepercayaan sebuah pohon filogenetik (Hall, 2001). Semakin besar nilai bootstrap yang digunakan maka semakin tinggi kepercayan topologi pohon hasil rekonstruksi yang didasarkan atas distribusi karakter dalam data akibat pengaruh efek acak (Ubaidillah dan Sutrisno 2009).

Pohon filogenetik menggambarkan bahwa semua sampel terbagi menjadi dua kelompok besar. Sampel sagu 03, 04, 05, 06, 07, 09, 10, 11, 13 dan 14 berada pada satu kelompok yang sama yang didukung dengan nilai bootstrap 61, sedangkan sampel sagu 01, 02, 08, 12 dan 15 dengan nilai bootstrap 44. Seluruh sampel dalam penelitian ini juga berada dalam satu kelompok besar dengan sequens Metroxylon warbugii yang berasal dari GenBank (kode akses KT312926.1). Pengelompokan ini didukung dengan nilai bootstrap 37 . 


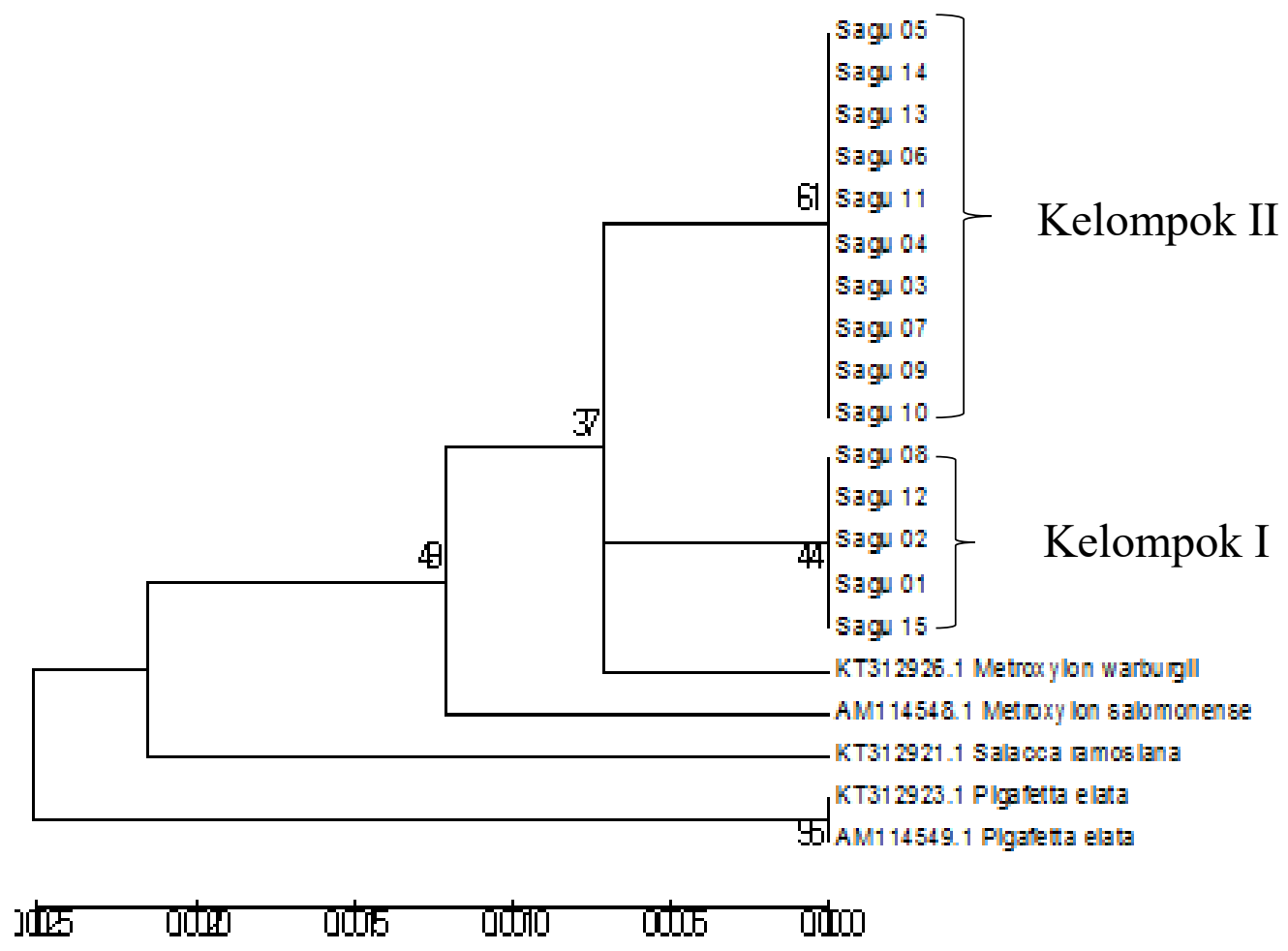

Gambar 5. Diagram filogenetik tanaman sagu berdasarkan marker gen mat-K

\section{Jarak genetik}

Tabel matriks jarak genetik aksesi sagu dan palmae lain ditampilkan pada Tabel 9. Pengelompokkan sampel sagu terdiri dari haplotipe $1(01,02,08,12$, dan 15) dan haplotipe $2(03,04,05,06$, 07, 09, 10, 11, 13, dan 14). Haplotipe 1 dan haplotipe 2 memiliki jarak genetik 0,001 (Tabel 9) yang artinya hubungan kekerabatan kedua haplotipe ini sangat dekat. Menurut Tallei et al., (2016), semakin sedikit nilai jarak genetik antara dua organisme, semakin dekat pula hubungan kekerabatan keduanya.

Jarak genetik antara KT312926.1 Metroxylon warburgii dan AM114548.1 Metroxylon salomonense dengan haplotipe 1 adalah 0.001 , sedangkan haplotipe 2 jika dibandingkan dengan KT312926.1 Metroxylon warburgii memiliki jarak genetik 0.003. jarak genetik antara KT312923.1 Pigafetta elata dan AM114549.1 Pigafetta elata dengan haplotipe 1 adalah 0.006, sedangkan dengan KT312921.1 Salacca ramosiana memiliki jarak genetik 0.004. Haplotipe 2 jika dibandingkan dengan KT312926.1 Metroxylon warburgii memiliki jarak genetik 0.001 dan AM114548.1 Metroxylon salomonense memiliki jarak genetik 0.003. Jika dibandingkan dengan KT312923.1 Pigafetta elata, KT3129 21.1 Salacca ramosiana dan AM1145 49.1 Pigafetta elata, maka jarak genetiknya adalah 0.004 . Famili falmae yang paling dengat dengan tanaman sagu adalah $M$. warburgi. Penelitian sebelumnya juga mengungkapkan bahwa $M$. sagu berkerabat dekat dengan $M$. warburgii (Abbas et al. 2020)

Individu-individu yang memiliki nilai jarak genetik rendah mengindikasikan bahwa individu-individu tersebut memiliki hubungan kekerabatan yang semakin dekat, sedangkan bila jarak genetiknya tinggi maka individu-individu tersebut memiliki hubungan kekerabatan yang jauh (Somura et al. 2013). 
Tabel 9. Matriks jarak genetik tanaman sagu berdasarkan marker gen mat-K

\begin{tabular}{|c|c|c|c|c|c|c|c|c|c|c|c|c|c|c|c|c|c|c|c|c|c|}
\hline No & ID Sampel & 1 & 2 & 3 & 4 & 5 & 6 & 7 & 8 & 9 & 10 & 11 & 12 & 13 & 14 & 15 & 16 & 17 & 18 & 19 & 20 \\
\hline 1 & Sagu 01 & & & & & & & & & & & & & & & & & & & & \\
\hline 2 & Sagu 02 & 0.000 & & & & & & & & & & & & & & & & & & & \\
\hline 3 & Sagu 03 & 0.001 & 0.001 & & & & & & & & & & & & & & & & & & \\
\hline 4 & Sagu 04 & 0.001 & 0.001 & 0.000 & & & & & & & & & & & & & & & & & \\
\hline 5 & Sagu 05 & 0.001 & 0.001 & 0.000 & 0.000 & & & & & & & & & & & & & & & & \\
\hline 6 & Sagu 06 & 0.001 & 0.001 & 0.000 & 0.000 & 0.000 & & & & & & & & & & & & & & & \\
\hline 7 & Sagu 07 & 0.001 & 0.001 & 0.000 & 0.000 & 0.000 & 0.000 & & & & & & & & & & & & & & \\
\hline 8 & Sagu 08 & 0.000 & 0.000 & 0.001 & 0.001 & 0.001 & 0.001 & 0.001 & & & & & & & & & & & & & \\
\hline 9 & Sagu 09 & 0.001 & 0.001 & 0.000 & 0.000 & 0.000 & 0.000 & 0.000 & 0.001 & & & & & & & & & & & & \\
\hline 10 & Sagu 10 & 0.001 & 0.001 & 0.000 & 0.000 & 0.000 & 0.000 & 0.000 & 0.001 & 0.000 & & & & & & & & & & & \\
\hline 11 & Sagu 11 & 0.001 & 0.001 & 0.000 & 0.000 & 0.000 & 0.000 & 0.000 & 0.001 & 0.000 & 0.000 & & & & & & & & & & \\
\hline 12 & Sagu 12 & 0.000 & 0.000 & 0.001 & 0.001 & 0.001 & 0.001 & 0.001 & 0.000 & 0.001 & 0.001 & 0.001 & & & & & & & & & \\
\hline 13 & Sagu 13 & 0.001 & 0.001 & 0.000 & 0.000 & 0.000 & 0.000 & 0.000 & 0.001 & 0.000 & 0.000 & 0.000 & 0.001 & & & & & & & & \\
\hline 15 & Sagu 15 & 0.000 & 0.000 & 0.001 & 0.001 & 0.001 & 0.001 & 0.001 & 0.000 & 0.001 & 0.001 & 0.001 & 0.000 & 0.001 & 0.001 & & & & & & \\
\hline 16 & KT312926.1_Metroxylon_warburgii & 0.001 & 0.001 & 0.001 & 0.001 & 0.001 & 0.001 & 0.001 & 0.001 & 0.001 & 0.001 & 0.001 & 0.001 & 0.001 & 0.001 & 0.001 & & & & & \\
\hline 17 & AM114548.1_Metroxylon_salomonense & 0.001 & 0.001 & 0.003 & 0.003 & 0.003 & 0.003 & 0.003 & 0.001 & 0.003 & 0.003 & 0.003 & 0.001 & 0.003 & 0.003 & 0.001 & 0.003 & & & & \\
\hline 18 & KT312923.1_Pigafetta_elata & 0.006 & 0.006 & 0.004 & 0.004 & 0.004 & 0.004 & 0.004 & 0.006 & 0.004 & 0.004 & 0.004 & 0.006 & 0.004 & 0.004 & 0.006 & 0.006 & 0.007 & & & \\
\hline 19 & KT312921.1_Salacca_ramosiana & 0.004 & 0.004 & 0.004 & 0.004 & 0.004 & 0.004 & 0.004 & 0.004 & 0.004 & 0.004 & 0.004 & 0.004 & 0.004 & 0.004 & 0.004 & 0.003 & 0.006 & 0.006 & & \\
\hline 20 & AM114549.1_Pigafetta_elata & 0.006 & 0.006 & 0.004 & 0.004 & 0.004 & 0.004 & 0.004 & 0.006 & 0.004 & 0.004 & 0.004 & 0.006 & 0.004 & 0.004 & 0.006 & 0.006 & 0.007 & 0.000 & 0.006 & \\
\hline
\end{tabular}




\section{KESIMPULAN}

Bedasarkan hasil penelitian ini dapat disimpulkan sebagai berikut (1) aksesi tanaman sagu yang telah di koleksi oleh Konsorsium Riset sagu UNIPA secara morfologi berbeda pada fase Russet, (2) berdasarkan penanda molekuler maturase $\mathrm{K}$ (mat-K) 15 aksesi sagu yang dianalisis terbagi menjadi dua haplotipe, yaitu haplotipe 1 yang mengalami delesi pada basa nomor 5 (asam amino phenylalanine) dan haplotipe 2 yang tidak mengalami delesi sehingga memiliki asam amino phenylalanine, dan (3) Konstruksi filogenetik menunjukkan bahwa 15 aksesi sagu terbagi menjadi 2 kelompok, yaitu kelompok 1 dan kelompok 2. Kerabat yang paling dekat $M$. sagu adalah $M$. warburgii dengan jarak genetik 0.001.

\section{UAPAN TERIMA KASIH}

Penelitian ini dibiayai oleh Proyek Penelitian Riset Pengembangan yang berjudul "Transformasi invensi berbasis sagu menjadi inovasi yang berorientasi entrepreneurship dalam rangka mengakselerasi daya saing dan kemandirian Bangsa dibidang pangan" dengan kontrak No. 198/SP2H/AMD/LT/DRPM/2020.

Kepada Tim Peneliti dengan Ketua Prof. Dr. Ir. Barahima Abbas, M.Si dan Pengelola Riset Pengembangan Kementerian Riset, Teknologi dan Pendidikan Tinggi diucapkan terima kasih.

\section{DAFTAR PUSTAKA}

Abbas B, Bintoro MH, Sudarosono, Surahman M, Ehara H. 2009. Genetic relationship of sago palm (Metroxylon sagu Rottb.) in Indonesia based on RAPD markers. Biodiversitas 10 (4): 168-174. DOI: 10.13057/biodiv/d100402

Abbas B, Renwarin Y, Bintoro $\mathrm{MH}$, Sudarsono, Surahman M, Ehara H. 2010. Genetic Diversity of Sago Palm in Indonesia Based on
Chloroplast DNA (CpDNA) Markers. Biodiversitas 11 (3): 11217. DOI: 10.13057/biodiv/d110302. Abbas B, Tjolli I, Dailami M, Munarti. 2019. Phylogenetic of sago palm (Metroxylon sagu) and others monocotyledon based on mitochondrial Nad2 gene markers. Biodiversitas 20 (8): 2249-2256. DOI: $10.13057 /$ biodiv/d200820.

Abbas, B dan H. Ehara. 2012. Assessment genetic variation and relationship of sago palm (Metroxylon sagu Rottb.) in Indonesia based on specific expression gene (Wx genes) markers. African Journal of Plant Science. 6(12):314-320

Abbas B. 2018. Sago palm genetic resource diversity in Indonesia. In: Ehara H, Toyoda Y, Johnson D (eds.). Sago Palm: Multiple Contributions to Food Security and Sustainable Livelihoods. Springer, Singapore. DOI: 10.1007/978-98110-5269-95.

Abbas B, Kabes RJ, Mawikere NL, Ruimassa RMR, Maturbong RA. 2020. DNA barcode of Metroxylon sagu and other palm species using matK gene. Biodiversitas 21: 40474057

Abbas B, Tjolli I, Munarti. 2020. Genetic diversity of sago palm (Metroxylon sagu) accessions based on plastid cpDNA matK gene as DNA barcoding. Biodiversitas 21: 219225.

Altschul, S. F., W. Gish., W. Miller., E. W. Myers. 1990. Basic local aligment search tool. Molecular Biology. 215(3):403-10.

Barthet, M. M and K. W. Hilu. 2007. Expression of matK: functional and evolutionary implications. American Journal of Botany. 94(8): 1402-1412.

Budianto, J. 2003. Kebijakan penelitian sagu di Indonesia. Makalah Utama dalam seminar Sagu Untuk 
Ketahanan Pangan. Prosiding Seminar Nasional Sagu, Manado, 6 Oktober 2003. Puslitbang Perkebunan, Bogor.

Chase, M. W., R. S. Cowan, P. M. Hollingsworth, C. Van Den Berg, S. Madrin'an, G. Petersen, O. Seberg, T. Jorsensen, K. M. Cameron, M. Carine, N. Pedersen, T. A. J. Hedderson, F. Conrad, G. A. Salazar, J. E. Richardson, M. L. Hollingsworth, T. G. Barraclough, L. Kelly, and M. Wilkinson. 2007. A proposal for a standardised protocol to barcode all land plants. Taxon 56: 295-299.

Daniels N. M, A. Gallant, J. Peng, L. J. Cowen, M. Baym, and B. Berger. 2013. Compressive genomics for protein databases. Bioinformatics. 29:1283-1290.

Elviana 2010. Keragaman genetik kloroplas (cpDNA) bangkirai (Shorea laevis Ridl.) di Kalimantan berdasarkan penanda PCR-RFLP dan sekuens sebagian wilayah trnl-f [skripsi]. Bogor (ID): Fakultas Kehutanan, Institut Pertanian Bogor.

Flach, M. 1983. The Sago Palm Domestication Exploitation and Product. FAQ Plant Production and Protection Paper. Roma.

Hall, B. G. 2001. Phylogenetic Trees Made Easy: A How - To Manual for Molecular Biologists. Sinauer Associates, Inc. Sunderland, Massachusetts, USA

Harsanto, P. B. 1986. Budidaya dan Pengelolaan Sagu. Kanisius. Yogyakarta.

Hollingsworth, P. M., S. W. Graham, and D. P. Little. 2011. Choosing and Using a Plant DNA Barcode. PLoS ONE. 6(5):1-13.

Kress, W. J and D. L. Erickson. 2007. A two-locus global DNA barcode for land plants: The coding rbcL gene complements the noncoding trnH-
psbA spacer region. PLoS ONE 2: e508. doi: 10.1371/journal.pone.0000508.

Kress, W. J and D. L. Erickson. 2008. DNA Barcoding a Windfall for Tropical Biology? Biotropica, 40(4): $\quad 405-408$ DOI: 10.1111/j.1744-7429. 2008.00426. $\mathrm{X}$

Kress, W. J., K. J. Wurdack, E. A. Zimmer, L. A. Weigt, and D. H. Janzen. 2005. Use of DNA barcodes to identify flowering plants. Proceedings of the National Academy of Sciences USA, 102: 8369-8374.

Kuzmina, M. L, K. L. Johnson, H. R. Barron, and P. D. N. Herbert. 2012. Identification of vascular plants of Churchill, Manitoba, using a DNA barcode library. BMC Ecology 12:1-11. http://dx.doi.org/10.1186/14726785-12-2

Lahaye, R., M. Van Der Bank, D. Bogarin, J. Warner, F. Pupulin, G. Gigot, O. Maurin, S. Duthoit, T. G. Barraclough, and V. Savolainen. 2008. DNA barcoding the floras of biodiversity hotspots. Proceedings of the National Academy of Sciences USA, 105: www.pnas.org_cgi_doi_10.1073_p nas.0709936105 Diakses 18 Maret 2019

Lawodi, E. N, T. E. Tallei, F. R. Mantiri, and B. J. Kolondam. 2013. Variasi genetik tanaman tomat dari beberapa tempat di Sulawesi berdasarkan gen matK. Pharmacon 2:114-121

Nugraha F, D. I. Roslim, Y. P Ardilla, and Herman. 2014. Analysis of partial gene sequence Ferritine2 on Rice Plants (Oryza sativa L.) Indragiri Hilir, Riau. Biosaintifika. 6(2):7079.

Open Course Ware. 2009. Asam nukleat (nucleic acid) [terhubung berkala] 
http://.ocw.usu.ac.id/.../bbc115_slid e_asam_nukleat_atau_nucleic_acid. pdf [07 Mei 2019].

Riyanto, R., I. Widodo., B. Abbas. 2018. Morphology, Growth and genetic variations of sago palm (Metroxylon sagu) seedlings derived from seeds. Biodiversitas. 19(2):682-688.

Saitou, N and T. Imanishi. 1989. Relative efficiencies of the fitch-margoliash, maximum-parsimony, maximumlikelihood, minimum-evolution, and neighbor-joining methods of phylogenetic tree construction in obtaining the correct tree. Molecular Biology and Evolution. 6(5).

Sambrook. J., D. W. Russell. 2001. Molecular cloning a laboratory manual. Planview, New York: Cold Spring Harbor Laboratory Press.

Somura, H., H. Hori, and Y. Manome. 2013. Nycticebus bengalensis mitochondrion, complete genome. https://www.ebi.ac.uk/ena/dataview /KC 977312.

Taberlet, P., E. Coissac., F. Pompanon., L. Gielly., C. Miquel., A. Valentini., T. Vermat., G. Corthier., C. Brochmann, and E. Willerslev. 2007. Power and limitations of the chloroplast trnL (UAA) intron for plant DNA barcoding. Nucleic Acids Research. 35(3):e14.

Tallei, T. E., R. E. Rembet, J. J Pelealu, and B. J Kolondam. 2016. Sequence Variation and Phylogenetic Analysis of Sansevieria trifasciata (Asparagaceae).

Bioscience

Research 13(1): 01-07.

Tamura K., D. Peterson, N. Peterson, G. Stecher, M. Nei, and S. Kumar. 2011. MEGA5: Molecular Evolutionary Genetics Analisis using Maximum Likelohood, Evolutionary Distence, and maximum Parsimony Methods. Molecular Biology and Evolution 28:2731-2739
Tarigan, D. D. 2001. Sagu memantapkan swasembada pangan. Warta Penelitian dan Pengembangan Pertanian 23 (5), 1-3.

Tenda E. T, H. Novarianto, and J. Limbongan. 2006. Biodiversity of sago palm in Indonesia and conservation strategy. Proceeding of the eight International sago palm symposium. Pp. 239.

Ubaidillah, R dan H. Sutrisno. 2009. Pengantar Biosistemik: Teori dan Praktikum. LIPI Press, Jakarta

Xiong, J. 2006. Essential Bioinformatics. Cambridge (GB): Cambridge University Pr. 